useful to see how rural ethnicity is created out of the structures and symbols of everyday life.

Still, this remains a Lese-centric analysis. I can see why Lese men maintain Efe partners who give them honor, reinforce their sense of superiority, and mediate their relations with neighboring houses. But what Grinker fails to explain is why the Efe put up with the relationship. Do they interpret Lese/Efe interactions through a set of counter models and symbols whereby the inequality is reversed? Are they oblivious to the structural and symbolic inequality in the Lese house? Perhaps it is possible after all that they endure the degradation because they need access to Lese gardens.

\title{
Coffee, Society, and Power in Latin America, edited by William Roseberry, Lowell Gudmundson, and Mario Samper Kutschbach; Baltimore: The Johns Hopkins University Press, 1995. 304 pp.
}

\author{
Reviewed by Deborah Sick, Research Associate, Department of \\ Anthropology, McGill University.
}

Stemming from a 1986 conference in Costa Rica on the history of coffee, these diverse readings are linked by a common analysis of a single commodity within a historical materialist framework, covering the period from roughly 1830 to 1950 . Though much has been written concerning agricultural export economies, the impacts of export commodity production are often characterized in broad, overgeneralized terms. The commodity approach employed in this collection uses the commonalities of coffee production, marketing, and distribution as points of comparison, while stressing the importance of diverse regional contexts.

As Roseberry emphasizes in the introduction to the volume, despite certain common transformations, "radically different social, economic, political, and cultural contexts" (p. 30) have resulted in the regional variations found throughout Latin American coffee producing societies. It is through Roseberry's introduction that the material presented in the following essays really takes shape, for it is here that a comprehensive framework for comparative analysis is constructed. Roseberry provides an informative summation of the historic development of coffee production in Latin America and a provocative discussion of the analytic themes that bind these essays together, and points out areas where research has been lacking. In his discussion of land tenure and labor mobilization; the role of merchants, processors and markets; and state ideologies and politics, he emphasizes both commonalities and regional differences, establishing a comparative framework that "concentrates on the local and particular, with questions about the appropriation and mobilization of land and labor, the investment of capital and the organization of markets, and the administration and imagination of power" (p. 31).

Michael F. Jiménez's initial contribution sets the scene by examining the international coffee market in the century preceding the Great Depression. The essay focuses on the rise in coffee consumption in the U.S. Though many producers exported primarily to Europe, 
the tremendous impact of the U.S. (particularly during times of war) on the world coffee economy cannot be overlooked. Jiménez's fascinating account looks at the rise of a new international mercantile elite and the way in which it shaped consumer taste and increased demand by fashioning a discourse linked to perceptions and practices in the American home and workplace. The remaining eight articles are case studies focusing on a number of overlapping themes in Brazil, Puerto Rico, Costa Rica, Colombia, Guatemala, and El Salvador. Two of these essays-- Stolcke's and Samper's-- are comparative efforts.

Verna Stolcke (the only one in this collection to focus on family labor) compares different forms of labor appropriation in various coffee-producing regions. The essay looks at how the hidden dimension of family labor allowed large producers to shift the costs of production and reproduction to the household during economic crises. She concludes by examining how changes in states' policies variously affected the organization of family labor.

The essays by Fernando Picó (on Puerto Rico) and Lowell Gudmundson (on Costa Rica) analyze the relationship between the expansion of coffee production and changing patterns of land tenure, ownership, and inheritance. In both cases the authors find not a dramatic increase in latifundia, but a substantial rise in medium-sized family farms. Gudmundson's data are particularly rich, and his analysis of the impacts of land scarcity on class formation and inheritance patterns is insightful, especially as it affected female inheritance.

Echoing the theme of the "'internalization' of external conditions" (p. 169), Mario Samper Kutschbach compares the social impact of crises in the international coffee market during the 1920s and 1930s on large and small units of production in Costa Rica and Colombia. Through a comparison of the social and political contexts encompassing coffee production in each country, he argues convincingly that the ability of coffee producers to weather adverse economic conditions is not linked solely to inherent characteristics of the type of production unit (as Stolcke suggests), but rather depends on specific social and political factors in each region. Questions concerning the impact of coffee production on forms of labor organization and appropriation are addressed in the essays by Maricio Font (on Brazil) and David McCreery (on Guatemala). Font argues that the structural changes taking place in Sao Paulo between 1880 and 1930 were the result of complex processes and did not result in the homogenous conversion of colonos (unique type of sharecropper/ laborers) to proletarians, as some have argued. Rather, a process of differentiation was affecting both colonos and elites alike. Unable to monopolize land and state power, rural elites could not prevent independent production by smaller cultivators, and various forms of petty and household production emerged.

David McCreery examines the relationship between finqueros (large farmers), laborers, and the state in Guatemala from 1920-1945. He discusses not just the contexts in which coercive labor laws were enacted, but the processes of "negotiation," resistance, and rebellion that accompanied such measures until the 1940s. At that time economic necessity, brought about by population growth and land scarcity, became the basis for compelling labor to seek plantation work.Héctor Pérez Brignoli's essay attempts to untangle the complicated web of explanations surrounding the 1932 rebellion in El Salvador. Following a discussion of several single-cause political and social explanations, Brignoli argues that a number of disparate factors led to the violent revolt involving coffee peons, Indian peasants, and communist leaders. Although agrarian unrest, changes in land distribution that accompanied the expansion of coffee, and communist social agitation 
fueled rural unrest, much evidence indicates that racism and ethnic conflict between Indians and mestizos were equally important factors.

The final essay in the collection returns to the question of the power of large growers. Michael Jiménez's analysis of the alliances and conflicts involving hacendados, smallholders, tenants, landless laborers, and the state demonstrates the complex ways in which power was contested and negotiated during the early twentieth century in Colombia. Continually challenged from below, unable to ally themselves with other rising elite forces, and unwilling to concede that the "inferior classes" could become the basis of a productive society, the power of large planters was limited. In the end, Jiménez concludes, though without explanation, that it was these weaknesses that led to the social conflicts and violence of Colombia's recent past.

The ten essays in this book present a unique and important contribution to the study of political economy in Latin America. Though some articles contain minor inconsistencies, (that could be corrected with better proofreading) each author attempts, with varying degrees of success, to analyze the complex factors that have shaped modern Latin American coffee-producing societies. It is an important book, not just for scholars of Latin America, but for anyone interested in understanding the ways in which export agriculture impacts society and how power is created, used, contested, and negotiated given particular global conditions and local contexts.

\section{Managing the Global Commons. By William Nordhaus; Cambridge, MA: The MIT Press. 1994. 213 pp., one Appendix.}

\section{Reviewed by Jonathan A. Lesser, Green Mountain Power Company, South Burlington, VT 05402-0850}

It is hard to conceive of a more difficult policy issue to analyze than global climate change. The climatological dynamics are mind-numbingly complex, while the scope of the policy issues raised, encompassing economic, ethical, social, and even political aspects, seems limitless. Views on global climate change range from doom sayers who predict, and perhaps even look forward to, humanity's eventual demise; to nay sayers and Pollyannas, who either deny the existence of global climate change or even welcome it.

Any author willing to analyze the subject dispassionately and suggest concrete policy approaches invites wilting criticism. Yet it is crucially important to develop just such analyses, economic or otherwise, for without them decision makers will have nothing on which to base policies except thoughtless bilge.Managing the Global Commons does not pretend to be the definitive policy analysis of global climate change. Instead, its author, economist William Nordhaus of Yale University, develops a dynamically linked economic and environmental model that provides insights into economically efficient strategies to address global climate change. Thankfully, Nordhaus does not pretend, at least in this book, to be the moral philosopher of our time, endlessly debating the "fairness" of imposing climate change on future generations. For clarity of purpose and exposition, he 